\title{
Penerapan Sistem Teknologi Informasi Terhadap Peningkatan Kinerja Pegawai Pada Kantor Unit Pelaksana Teknis Dinas (UPTD) Pendidikan Tanete Riattang Barat Kabupaten Bone
}

\author{
Firman H \\ Sekolah Tinggi Ilmu Administrasi Puangrimaggalatung \\ Email: firmanhamzah119@gmail.com
}

\begin{abstract}
Abstrak
Perkembangan teknologi informasi direspon oleh organisasi dengan mendesaian sistem informasi berbasis teknologi komputer, sistem ini dapat memberikan nilai tambah bagi organisasi jika organisasi didesain menjadi sistem informasi yang efektif. Tujuan penelitian (1) untuk mengetahui penerapan sistem administrasi terhadap peningkatan kinerja pegawai, dan (2) Untuk mengetahui faktor yang mempengaruhi peningkatan kinerja pegawai. Penelitian ini menggunakan jenis penelitian kombinasi pendekatan kuantitatif (metode survey) dan pendekatan kuantitaf. Metode survey adalah metode yang mengambil contoh data dari satu populasi dan menggunakan kuesioner sebagai alat pengumpulan data yang pokok. Hasil penelitian ini adalah (1) Penerapan sistem administrasi terhadap peningkatan kinerja pegawai telah optimal dan dilakukan melalui kemampuan kerja, motivasi kerja, dan (2) Peran pemimpin dan dukungan pegawai, juga tidak sulit mengarahkan, meningkatkan kerjasama internal kantor maupun di lingkungan masyarakat.
\end{abstract}

\section{PENDAHULUAN}

\section{Latar Belakang Masalah}

Kinerja organisasi sangat dipengaruhi oleh penguasan informasi dari pegawai suatu organisasi. Dengan aplikasi teknologi maka organisasi akan mengalami perubahan sistem manajemen, dari sistem tradisional ke sistem manajemen kontemporer. Teknologi informasi berkaitan dengan pelayanan, hal tersebut dikarenakan salah satu dimensi dari kualitas pelayanan adalah kecepatan pelayanan dimana dimensi tersebut dapat dikaitkan dengan teknologi informasi, dengan adanya teknologi informasi maka pelayanan yang diberikan khususnya pada organisasi jasa, akan semakin cepat dan akurat. Salah satu hal yang mempengaruhi kinerja instnasi pemerintah daerah adalah pemanfaatan teknologi informasi.

Suatu organisasi, baik organisasi pemerintahan maupun organisasi swasta, bahkan setiap individu pun, tidak akan luput dari perlunya kegiatan pengarsipan, karena dari arsiplah diperoleh informasi dan data yang diperlukan dalam melanjutkan kehidupan organisasi. Informasi dan data bukan hanya diperoleh melalui komunikasi dan interaksi dengan orang atau organisasi lain, tetapi dapat pula diperoleh dari arsip-arsip yang tersimpan di dalam organisasi sendiri.

Pada Kantor Unit Pelaksana Teknis Dinas (UPTD) Pendidikan Kecamatan Tanete Riattang Barat, kenyataan yang terlihat saat ini adalah kinerja pegawai belum dapat terwujudkan dengan baik hal ini karena kurangnya pemanfaatan teknologi berbasis informasi bagi pegawai sehingga kinerja pegawai belum maksimal.

Sehubungan dengan latar belakang di atas maka penulis terdorong untuk menyusun sebuah tulisan dalam bentuk skripsi dengan judul "Penerapan Sistem Teknologi Informasi Terhadap Peningkatan Kinerja Pegawai Pada Kantor Unit Pelaksana Teknis Dinas (UPTD) Pendidikan Kecamatan Tanete Riattang Barat Kabupaten Bone".

\section{Rumusan Masalah}

1. Sejauhmana penerapan sistem administrasi terhadap peningkatan kinerja pegawai pada Kantor Unit Pelaksana Teknis Dinas 
(UPTD) Pendidikan Kecamatan Tanete Riattang Barat Kabupaten Bone?

2. Faktor-faktor apa yang mempengaruhi peningkatan kinerja pegawai pada Kantor Unit Pelaksana Teknis Dinas (UPTD) Pendidikan Kecamatan Tanete Riattang Barat Kabupaten Bone?

\section{Tujuan dan Manfaat Penelitian}

\section{Tujuan Penelitian}

a. Untuk mengetahui penerapan sistem administrasi terhadap peningkatan kinerja pegawai pada Kantor Unit Pelaksana Teknis Dinas (UPTD) Pendidikan Kecamatan Tanete Riattang Barat Kabupaten Bone.

b. Untuk mengetahui faktor yang mempengaruhi peningkatan kinerja pegawai pada Kantor Unit Pelaksana Teknis Dinas (UPTD) Pendidikan Kecamatan Tanete Riattang Barat Kabupaten Bone.

\section{Manfaat Penelitian}

a. Manfaat Praktis

Sebagai usaha untuk menunjukkan perbandingan dan acuan untuk meningkatkan kinerja pimpinan dan pegawai dapat menerapkan peranannya.

b. Manfaat Teoritis

Sebagai sarana belajar untuk memahami permasalahan yang menjadi topik kajian. Dan bahan informasi, referensi kepada pihak-pihak lain yang ingin mengkaji permasalahan yang sama.

\section{TINJAUAN PUSTAKA}

\section{Pengertian Penerapan}

Penerapan dimaksudkan sebagai usaha atau upaya yang dilakukan untuk mewujudkan atau merealisir sesuatu konsep, gagasan ide atau sesuatu teori dalam kehidupan yang sesungguhnya.

Penerapan yang dimaksudkan dalam pembahasan ini adalah Sistem administrasi, dimana merupakan suatu konsep dan bahkan telah menjadi teori, dalam kegiatan organisasi atau unit kerja.

Organisasi yang dimaksud sebagai tempat penerapan sistem administrasi adalah pegawai pada Kantor Unit Pelaksana Teknis
Dinas (UPTD) Pendidikan Kecamatan Tanete Riattang Barat Kabupaten Bone atau dengan kata lain penerapan yang dimaksud dalam pembahasan ini adalah pemanfaatan atau perwujudan administrasi dalam peningkatan kinerja pegawai pada Kantor Unit Pelaksana Teknis Dinas (UPTD) Pendidikan Kecamatan Tanete Riattang Barat Kabupaten Bone

\section{A. Konsep tentang Sistem}

Menurut Sumantri dalam Inu Kencana Syafiie (2003:90) Sistem adalah sekelompok bagian-bagian yang bekerja bersama-sama untuk melakukan suatu maksud, apabila salah satu bagian rusak atau tidak dapat menjalankan tugasnya maka maksud yang hendak dicapai tidak dapat terpenuhi atau setidak-tidaknya sistem yang sudah terwujud akan dapat gangguan.

Menurut Pamudji (2007:112) sistem adalah suatu kebulatan atau keseluruhan yang kompleks atau terorganisir, suatu himpunan atau perpaduan hal- hal atau bagian-bagian yang membentuk suatu kebulatan atau keseluruhan yang kompleks atau utuh.

Berdasarkan dari defenisi diatas maka sistem merupakan kesatuan yang utuh dari suatu rangkaian, yang kait- mengait satu sama lain. Bagian atau anak cabang dari suatu sistem, menjadi induk dari rangkaian selanjutnya. Begitulah seterusnya sampai pada bagian terkecil. Rusaknya salah satu bagian akan mengganggu kestabilan sistem itu sendiri secara keseluruhan.

\section{Pengertian Teknologi Informasi}

Menurut O'Brien (2006:28) teknologi adalah suatu jaringan komputer yang terdiri atas berbagai komponen pemprosesan informasi yang menggunakan berbagai jenis hardware, software, manajemen data, dan teknologi jaringan informasi.

Menurut Aji (2005:6) informasi adalah data yang terolah dan sifatnya menjadi data lain yang bermanfaat dan biasa disebut informasi.

Teknologi informasi adalah fasilitasfasilitas yang terdiri dari perangkat keras dan 
perangkat lunak dalam mendukung dan meningkatkan kualitas informasi untuk setiap lapisan masyarakat secara cepat dan berkualitas. Teknologi informasi adalah suatu studi perancanga, implementasi, pengembangan, dukungan atau manajemen sistem informasi berbasis komputer.

Pemanfaatan teknologi informasi adalah perilaku/ sikap akuntan menggunakan teknologi informasi untuk menyelesaikan tugas dan meningkatkan kinerjanya. Pemanfaatan teknologi informasi merupakan manfaat yang diharapkan oleh pengguna sistem infomasi dalam melaksanakan tugasnya atau perilakunya dalam menggunakan teknologi pada saat melakukan pekerjaan.

Sistem informasi yang diterapkan di suatu organisasi akan berbeda dengan sistem informasi yang diterapkan pada organisasi lainnya, karena akan tergantung kepada luas lingkup organisasi yang bersangkutan. Setiap organisasi perlu merancang masing-masing sistem informasi, dan pengembangannya perlu disesuaikan dengan kebutuhan dari organisasi yang bersangkutan.

Perancangan sistem informasi termaksud dapat disesuaikan dengan rencana pengembangan di masa depan, untuk jangka pendek maupun jangka panjang, dikaitkan dengan faktor-faktor penting lainnya.

Perancangan sistem informasi yang luas dan rumit kiranya tidak cukup dilakukan hanya oleh pimpinan organisasi seorang diri, tetapi perlu dibantu oleh seorang ahli analisis sistem dan ahli komputer. Sistem informasi akan dapat dilaksanakan dengan efektif dan efisien, apabila keadaan organisasi yang bersangkutan benarbenar menunjangnya.

\section{Konsep tentang Peningkatan Kinerja}

Kinerja dapat diartikan sebagai gambaran mengenai tingkat pencapaian pelaksanaan suatu kegiatan atau program atau kebijakan dalam mewujudkan sasaran, tujuan, misi dan visi organisasi yang tertuang dalam rencana strategi suatu organisasi.

Menurut Dessler (2007:32), Kinerja merupakan prosedur yang meliputi (1)
Penetapan Standar kinerja; (2) Penilaian Kinerja aktual pegawai dalam hubungan dengan standar-standar ini; (3) Memberi umpan balik kepada pegawai dengan tujuan memotivasi orang tersebut untuk menghilangkan kemerosotan kinerja atau terus berkinerja lebih tinggi lagi.

Ada beberapa indikator yang biasanya digunakan untuk mengukur kinerja (Dwiyanto, 2002:114) itu sebagai berikut:

1. Produktivitas

Konsep produktivitas tidak hanya mengukur tingkat efisiensi, tetapi juga efektivitas pelayanan. Produktivitas pada umumnya dipahami sebagai rasio antara input dengan output. konsep produktivitas dirasa terlalu sempit dan kemudian General Accounting Office (GAO) mencoba mengembangkan satu ukuran produktivitas yang lebih luas dengan memasukkan seberapa besar pelayanan publik itu memiliki hasil yang diharapkan sebagai salah satu indikator kinerja yang penting.

2. Kualitas Layanan

Kualitas layanan cenderung menjadi semakin penting dalam menjelaskan kinerja organisasi pelayanan publik. Banyak pandangan negatif yang terbentuk mengenai organisasi publik muncul karena ketidakpuasan masyarakat terhadap kualitas layanan yang diterima dari pegawai publik. Dengan demikian, kepuasan masyarakat terhadap layanan dapat dijadikan indikator kinerja organisasi publik. Keuntungan utama menggunakan kepuasan masyarakat sebagai indikator kinerja adalah informasi mengenai kepuasan masyarakat seringkali tersedia secara mudah dan murah.

3. Responsivitas

Responsivitas adalah kemampuan organisasi untuk mengenali kebutuhan masyarakat, menyusun agenda dan prioritas pelayanan, dan mengembangkan programprogram pelayanan publik sesuai dengan kebutuhan dan aspirasi masyarakat.

4. Responsibilitas 
Responsibilitas adalah menjelaskan apakah pelaksanaan kegiatan organisasi publik itu dilakukan sesuai dengan prinsip-prinsip administrasi yang benar atau sesuai dengan kebijakan organisasi, baik yang eksplisit maupun implisit (Lenvine, 2000:96). Oleh sebab itu, responsibilitas bisa saja pada suatu ketika berbenturan dengan resposivitas.

5. Akuntabilitas

Dalam konteks ini, konsep akuntabilitas dapat digunakan untuk melihat seberapa besar kebijakan dan kegiatan itu konsisten dengan kehendak masyarakat banyak. Kinerja pegawai publik tidak hanya bisa dilihat dari ukuran internal yang dikembangkan oleh pemerintah, seperti pencapaian target. Kinerja sebaiknya harus dinilai dari ukuran eksternal, seperti nilainilai dan norma yang berlaku dalam masyarakat.

Kinerja atau prestasi kerja adalah hasil kerja yang dicapai oleh seorang karyawan melalui usaha dan segala kemampuan yang dimilikinya untuk mencapai tingkat prestasi dalam suatu kegiatan tidaklah mudah karena diperlukan berbagai upaya dan kemampuan keterampilan (skill), kemampuan pengetahuan (knowledge), kemampuan mentaati segala aturan (disiplin), lingkungan kerja yang menyenangkan (work condition) dan yang tidak kalah pentingnya adalah adanya motivasi yang tinggi.

Pengertian kinerja adalah upaya
aktivitas dalam menghasilkan output
berdasarkan pengembangan kerja yang terarah, terorganisir dan berkesinambungan untuk mencapai tujuan organisasi. Sopemo (2000:26).

Soeprihanto (2008:7) memberikan pengertian bahwa prestasi kerja seseorang tenaga kerja pada dasarnya adalah hasil kerja seseorang selama periode tertentu dibandingkan dengan berbagai kemungkinan misalnya, standar, target atau sasaran kerja atau kriteria yang telah ditentukan terlebih dahulu dan telah disepakati bersama, Lebih lanjut dikatakan bahwa setiap prestasi kerja karyawan perlu dinilai dan dievaluasi.

Untuk mengetahui sejauh mana tingkat hasil pelaksanaan pekerjaan karyawan, maka perlu diadakan suatu evaluasi terhadap hasil kerjanya. Di bawah ini dikemukakan beberapa hal yang berkaitan dengan penilaian kinerja antara lain :

a. Kinerja menunjukkan kepada penyelesaian tugas yang dilakukan oleh karyawan.

b. Penilaian kinerja adalah uraian sistematik dari kekuatan dan kelemahan berkenaan dengan pekerjaan tersebut dari seseorang ataupun kelompok.

c. Periode penilaian kinerja adalah rentang waktu dimana seseorang diamati prestasi kerjanya untuk membuat laporan formal.

Penilaian kinerja (performance appraisal) memainkan peranan yang sangat penting dalam peningkatan motivasi di tempat kerja. Karyawan menginginkan dan memerlukan balikan berkenaan dengan prestasi mereka dan penilaian menyediakan kesempatan untuk memberikan balikan kepada mereka. Jika kinerja tidak sesuai dengan standar, maka penilaian memberikan kesempatan untuk meninjau kemajuan karyawan dan untuk menyusun rencana peningkatan kinerja. Penilaian kinerja merupakan upaya membandingkan prestasi actual karyawan dengan prestasi kerja yang diharapkan darinya. Kinerja karyawan pada dasarnya adalah hasil kerja selama periode tertentu dibandingkan dengan berbagai kemungkinan, misalnya standar, target sasaran atau kriteria yang telah ditentukan terlebih dahulu dan telah disepakati bersama. Tentunya dalam penilaian tetap mempertimbangkan berbagai keadaan perkembangan yang mempengaruhi kinerja tersebut.

Dalam mengukur job performance maka masalah yang paling pokok adalah menetapkan kriterianya. Jika kriteria telah ditetapkan, langkah berikutnya adalah mengumpulkan informasi yang berhubungan dengan hal tersebut dari seseorang selama periode tertentu. Dengan membandingkan hasil ini terhadap 
standar yang dibuat untuk periode waktu yang bersangkutan, akan didapat level of performance seseorang. Penilaian kinerja adalah alat yang berfaedah tidak hanya untuk mengevaluasi kalangan karyawan. Dalam penilaian kinerja dinilai kontribusi karyawan kepada organisasi selama periode waktu tertentu. Umpan balik kinerja memungkinkan karyawan mengetahui seberapa baik mereka jika dibandingkan dengan standar organisasi.

Untuk menentukan ukuran tentang sukses dalam suatu pekerjaan amatlah sulit, karena seringkali pekerjaan itu begitu kompleks sehingga sulit. Ada ukuran output yang pasti. Hal seperti ini terutama terdapat pada jabatanjabatan yang bersifat administratif.

Sehubungan dengan hal tersebut maka dalam penelitian ini pendekatan untuk mengukur sejauh mana kinerja pegawai secara individual menggunakan kriteria antara lain :

a. kemampuan kerja sama

b. Inisiatif

c. Disiplin

d. Kepemimpinan bahwa:

. Pendapat diatas dapat disimpulkan

a. Prestasi yang dicapai adalah hasil kerja

b. Diukur berdasarkan standard dan waktu tertentu

c. Prestasi yang tinggi dinamakan manusia produktif

d. Jika prestasi dicapai dibawah standar disebut manusia tidak produktif.

Penilaian kinerja harus dilakukan secara objektif agar hasil penilaian yang diperoleh benar-benar bermanfaat, baik organisasi maupun bagi pegawai. Penilaian kecakapan, misalnya bagi para pegawai dapat menimbulkan rasa puas, karena pegawai menyadari bahwa hasil kerjanya memperoleh perhatian dari pemimpinnya.

Penilaian kerja menurut Akbar (2000:84) adalah suatu bentuk penilaian kinerja yang dapat ditunjukkan dalam mencapai tujuan kinerja. Penilaian kinerja tersebut dapat berupa jumlah aktivitas kerja yang dilakukan, tingkat pertumbuhan aktivitas kerja yang dicapai,
Kinerja atau prestasi kerja adalah hasil kerja yang dicapai oleh seorang karyawan melalui usaha dan segala kemampuan yang dimilikinya untuk mencapai tingkat prestasi dalam suatu kegiatan tidaklah mudah karena diperlukan berbagai upaya dan kemampuan keterampilan (skill), kemampuan pengetahuan (knowledge), kemampuan mentaati segala aturan (disiplin), lingkungan kerja yang menyenangkan (work condition) dan yang tidak kalah pentingnya adalah adanya motivasi yang tinggi.

Pengertian kinerja adalah upaya aktivitas dalam menghasilkan output berdasarkan pengembangan kerja yang terarah, terorganisir dan berkesinambungan untuk mencapai tujuan organisasi. Sopemo (2009:26).

Moh. Asad (2005:46), mengatakan bahwa orang yang tingkat prestasinya tinggi dinamakan orang yang produktif. Sebaliknya orang yang prestasinya tidak mencapai standar dikatakan sebagai orang yang tidak produktif atau performansinya rendah

jumlah keuntungan dan manfaat yang diperoleh serta menunjukkan persentase realisasi yang dapat dicapai.

Martoyo (2006:84) memberikan pengertian tentang penilaian prestasi kerja karyawan sebagai suatu proses melalui organisasi-organisasi mengevaluasi atau menilai prestasi kerja karyawan. Penilaian yang dilaksanakan dengan baik, tertib dan benar, dapat membantu meningkatkan motivasi kerja atau juga meningkatkan loyalitas dari anggota organisasi.

Amstrong (2005:178) lebih menekankan pada aspek manfaat yaitu untuk memastikan bahwa para manajer dan bawahan mereka menyadari apa yang perlu dikerjakan untuk memperbaiki prestasi kerja memberikan umpan balik agar orang-orang tahu dimana mereka berada, kemana harus pergi dan bagaimana cara mereka tiba disana. 


\section{Kerangka Konseptual}

Peningkatan kinerja pegawai dimaksudkan agar para pegawai dapat berprestasi dalam melaksanakan tugas-tugas yang menjadi tanggung jawabnya secara baik,

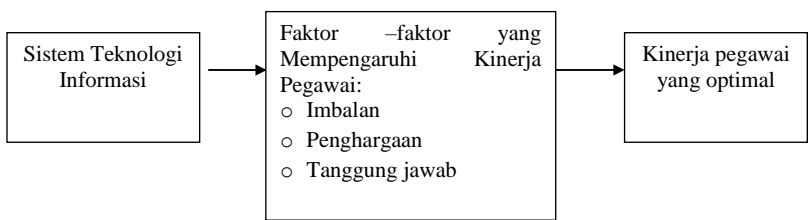

Gambar 1. Kerangka Konseptual

\section{METODE PENELITIAN}

Penelitian ini menggunakan kombinasi pendekatan kuantitatif (metode survey) dan pendekatan kuantitaf. Metode survey adalah metode yang mengambil contoh data dari satu populasi dan menggunakan kuesioner sebagai alat pengumpulan data yang pokok (Sugiono, 2011:90). Dengan memadukan kedua pendekatan tersebut diharapkan upaya pemahaman peran kepemimpinan dalam pengambilan keputusan. Faktor-faktor yang mempengaruhi kepemimpinan lurah terhadap kinerja pegawai serta pelayanan Kantor Unit Pelaksana Teknis Dinas (UPTD) Pendidikan Kecamatan Tanete Riattang Barat Kabupaten Bone kepada masyarakat dapat dilakukan secara lebih komprehensif.

\section{Lokasi Penelitian}

Penelitian ini dikarenakan di Kantor Unit Pelaksana Teknis Dinas (UPTD) Pendidikan Kecamatan Tanete Riattang Barat kabupaten Bone. Pemilihan lokasi penelitian dilakukan secara sengaja (purposive) dengan mempertimbangkan demi berlangsungnya suasana kerja yang baik dengan harapan akan lebih baik lagi.

\section{Populasi dan Sampel}

Populasi adalah wilayah generalisasi yang terdiri atas obyek dan subyek yang mempunyai kualitas dan karakteristik tertentu yang ditetapkan oleh peneliti untuk dipelajari kemudian ditarik kesimpulannya (Cahaya Andi, 2016:67). Populasi dalam penelitian ini mencakup seluruh pegawai benar dan efisien. Disinilah peranan pegawai negeri Sipil sebagai aparat pemerintah sangat menentukan keberhasilan pembangunan Nasional. Seperti pada bagan kerangka konseptual berikut:

Kantor Unit Pelaksana Teknis Dinas (UPTD) Pendidikan Kecamatan Tanete Riattang Barat sebanyak 17 orang.

Sedangkan pengertian sampel menurut Sofyan Effendy (2006:108) yaitu "keseluruhan atau sebagian dari populasi yang diambil dan mewakili populasi". Mengingat sedikitnya populasi, maka keseluruhan pegawai ditetapkan sebagai sampel penelitian. Hal ini sejalan dengan pendapat Arikunto (2007:120) yang mengatakan bahwa apabila subyeknya kurang dari 100 lebih baik diambil dan jika jumlah subyek lebih dari 100 maka dapat diambil antar $10 \%$ sampai dengan $15 \%$ atau lebih, disesuaikan dengan tenaga, waktu, dan kemampuan seorang peneliti.

Oleh karena jumlah populasi tidak dimungkinkan untuk melakukan penarikan sampel, maka penulis mengambil keseluruhan populasi (sampel penuh) sebagai sampel penelitian. Adapun jumlah sampel dalam penelitian adalah 17 orang.

\section{Teknik Pengumpulan Data}

a. Interview (wawancara terstruktur)

Wawancara ini penulis akan menggunakan instrumen wawancara terstruktur dimana penulis menggunakan pedoman wawancara yang telah tersusun secara sistematis dan lengkap.

b. Kuesioner

Kuesioner merupakan teknik pengumpulan data yang dilakukan dengan cara memberikan seperangkat pertanyaan atau pertanyaan tertulis kepada responden untuk dijawabnya.

c. Observasi (pengamatan terstruktur)

Pengamatan terstruktur adalah observasi yang telah dirancang secara sistematis, tentang apa yang akan diamati, kapan dan dimana tempatnya. 
d. Library Research (kepustakaan)

Teknik ini dilakukan dengan mencari literature-literature buku majalah, media cetak, media elektronik, perpustakaan dan Iain-lain yang ada hubungannya dengan judul penelitian.

\section{HASIL PENELITIAN DAN PEMBAHASAN}

organisasi. Perencanaan personil pemerintah sesuai dengan kebutuhan harus dilihat dari segi kuantitas dan kualitas.

Perencanaan dari segi kuantitas menyangkut jumlah pegawai yang perlu diadakan, dengan mempertimbangkan tenaga yang ada dibandingkan dengan beban kerja yang harus dilaksanakan.

Perencanaan dari segi kualitas menyangkut perkiraan kemampuan kerja yang harus dilaksanakan seluruh pegawai yang akan diadakan untuk masa mendatang.

Untuk itu perlu diketahui sumber tenaga kerja, yang dapat dimanfaatkan oleh dalam memenuhi kebutuhan mewujudkan teratasinya beban kerja, dengan demikian tidak ada bagian yang kekurangan tenaga.

Sistem dan kriteria pengisian kekurangan tenaga adalah sebagai berikut:

a. Bilamana terdapat kekurangan pegawai pada bagian tertentu, unit/bagian harus mempelajari kemungkinan mengatasinya dengan mempergunakan tenaga kerja yang sudah ada di Kantor Unit Pelaksana Teknis Dinas (UPTD) Pendidikan Kecamatan Tanete Riattang Barat Kabupaten Bone.

b. Untuk pengisian jabatan struktural harus memperhatikan beban tugas dan kemampuan atau keahliannya, agar proses pelaksanaan kebijakan yang akan diserahkan dapat berlangsung secara efisien dan efektif.

c. Untuk tenaga fungsional dan staf pengisian kekosongan dengan tenaga kerja dari dalam disamping memperhatikan beban kerja seseorang harus pula dititikberatkan untuk pengembangan karier.

\section{A. Penerapan sistem teknologi informasi terhadap peningkatan kinerja pegawai \\ 1. Mengefektifkan Pemanfaatan Pegawai}

Salah satu alternatif meningkatkan kinerja pegawai yaitu memaksimalkan pegawai yang ada sehingga dapat menangani volume dan beban kerja yang ada. Untuk itu diperlukan usaha menyusun perencanaan personil berdasarkan beban kerja d. Kesempatan pertama pengisian kekosongan itu diutamakan bagi pegawai dari jabatan yang lebih rendah, dengan memperhatikan prestasi kerja, dedikasi dan kemampuan kerja yang bersangkutan.

Hal tersebut berikut ini dikemukakan pendapat responden tentang sistem pengisian kekurangan tenaga struktural dan fungsional sebagaimana kriteria tersebut di atas.

Tabel 1. Pelaksanaan Kriteria Pengisian Kekurangan Tenaga

\begin{tabular}{|c|l|c|c|}
\hline No & \multicolumn{1}{|c|}{ Kriteria } & Frekuensi & $\%$ \\
\hline 1 & Dilaksanakan & 14 & 82,35 \\
2 & Kurang dilaksanakan & 3 & 17,65 \\
3 & Tidak dilaksanakan & - & - \\
\hline & Jumlah & 17 & 100 \\
\hline
\end{tabular}

Sumber; Data diolah tahun 2021

Sesuai tabel di atas, 14 responden menanggapi bahwa pengisian kekurangan tenaga dilakukan sesuai dengan kriteria yang ada dan 3 responden menyatakan kurang dilaksanakan dengan kriteria yang ada. Dengan demikian dalam hal ini pada prinsipnya telah dilakukan/dilaksanakan kriteria-kriteria yang ada dalam pengisian kekurangan yang dialami.

\section{Peningkatan Kemampuan Kerja Pegawai}

Pimpinan organisasi berpegang pada pendapat bahwa kemampuan kerja setiap pegawai di lingkungannya selalu dapat ditingkatkan. Kemampuan kerja yang tampak sehari-hari pada seseorang pegawai dipandang sebagai kemampuan sementara, bukan kemampuan maksimum dari yang bersangkutan. Di dalam diri mereka masih terdapat potensi yang bisa dikembangkan dalam rangka meningkatkan kemampuan kerjanya. Untuk itu pimpinan seharusnya terus 
mendorong agar setiap personil menggunakan kesempatan yang ada guna meningkatkan kemampuan kerjanya. Usaha itu dilakukan dalam batas-batas tidak merugikan organisasi/unit kerja, dalam arti dilakukan di luar jam kerja masing-masing.

Beberapa usaha yang dapat dilakukan pimpinan dalam meningkatkan kemampuan pegawai adalah:

a. Mendorong dan memberikan kesempatan kepada pegawai untuk meningkatkan pengetahuan dan keterampilannya melalui kursus-kursus, penataran, latihan kerja dan bahkan melanjutkan pendidikannya pada lembaga pendidikan formal yang lebih tinggi.

b. Mendorong dan menyediakan fasilitas agar setiap pegawai senang membaca berbagai majalah, koran dan buku-buku yang berhubungan dengan pekerjaannya.

c. Mendorong dan memberi kesempatan kepada setiap pegawai agar bersedia mengemukakan pendapat/pikiran, gagasan, kritik, inisiatif dan kreativitas untuk perbaikan kinerja dan programprogramnya. Pada giliran berikutnya bahkan berupa pemberian kesempatan untuk melaksanakan gagasan, inisiatif dan kreativitas yang setelah dimusyawarahkan dan diperkirakan akan banyak gunanya bagi kemajuan dan perkembangan organisasi.

d. Mendorong dan memberi kesempatan pada para pegawai untuk melakukan diskusidiskusi mengenai berbagai aspek didalam bidang/pekerjaan masing-masing. Diskusidiskusi ini memungkinkan terjadinya pertukaran pengetahuan dan pengalaman yang akan mengembangkan kemampuan kerja masing-masing.

Usaha pimpinan organisasi dalam meningkatkan kemampuan kerja pegawai tersebut di atas, tidak saja berguna bagi efisiensi dan efektivitas kerja, akan tetapi sangat besar pula manfaatnya bagi perwujudan suasana kerja yang diliputi kegairahan dan moral kerja yang tinggi.
Tabel 2. Pelaksanaan Kriteria Peningkatan Kemampuan Kerja

\begin{tabular}{|c|l|c|c|}
\hline No & \multicolumn{1}{|c|}{ Kriteria } & Frekuensi & $\%$ \\
\hline 1 & Dilaksanakan & 4 & 23,53 \\
2 & Kurang & 10 & 58,82 \\
& dilaksanakan & & 17,65 \\
\hline 3 & Tidak dilaksanakan & 3 & 100 \\
\hline
\end{tabular}

Sumber: Data diolah tahun 2021

Pada tabel di atas tergambar tanggapan responden tentang pelaksanaan kriteria peningkatan kemampuan kerja dimana sebanyak 10 responden menilai bahwa kriteria tersebut dilaksanakan, selanjutnya 4 responden menilai kurang dilaksanakan, dan 3 responden menilai tidak dilaksanakan.

Dengan demikian maka dapat dikatakan bahwa pelaksanaan kriteria-kriteria peningkatan kemampuan kerja kepada orang-orang yang pegawai telah dilakukan sebagai mana mestinya, meski harus diakui belum maksimal.

\section{Peningkatan Motivasi Kerja}

Setiap pegawai Kantor Unit Pelaksana Teknis Dinas (UPTD) Pendidikan Kecamatan Tanete Riattang Barat Kabupaten Bone dalam melaksanakan pekerjaannya sebagai perbuatan yang dilakukan secara sadar didorong oleh motif tertentu yang dapat bersifat obyektif dan subyektif.

Sehubungan dengan itu motif diuraikan sebagai kehendak, keinginan atau dorongan yang menyebabkan seseorang berbuat sesuatu secara sadar, Dorongan kerja yang kuat dan positif tampak dalam kesungguhan untuk bekerja keras, yang menggambarkan moral dan semangat kerja yang tinggi. Sebaliknya dorongan kerja yang lemah dan negatif, tampak dalam kurangnya kesungguhan dalam bekerja, yang menggambarkan moral atau semangat kerja yang rendah.

Sehubungan dengan itu moral atau semangat kerja diartikan sebagai suasana batin seorang petugas yang mempengaruhi sikapnya terhadap tugas atau pekerjaannya, yang langsung atau tidak langsung mempengaruhi 
pula terhadap tujuannya sebagai individu pula dalam mewujudkan tujuan organisasi kerjanya. Suasana batin yang bersifat subyektif itu dirasakan berupa perasaan puas dan tidak puas, senang dan tidak senang, bergairah dan tidak bergairah dan bersemangat atau tidak bersemangat.

Manifestasinya sama seperti motif yang mendorong dalam bekerja, berupa aktif, disiplin, rajin atau malas dan terdorong atau tidak terdorong dalam berpartisipasi untuk mewujudkan kegiatan-kegiatan pemerintah daerah yang terarah pada pencapaian tujuan.

Pendapat responden mengenai hal yang diuraikan di atas dapat dilihat pada tabel berikut:

Tabel 3. Pemberian Motivasi Kerja

\begin{tabular}{|c|l|c|c|}
\hline No & \multicolumn{1}{|c|}{ Kriteria } & Frekuensi & $\%$ \\
\hline 1 & Dilaksanakan & 12 & 70,59 \\
2 & Kurang & 3 & 17,65 \\
& dilaksanakan & & \\
3 & Tidak dilaksanakan & 2 & 11,76 \\
\hline & \multicolumn{1}{|c|}{ Jumlah } & 17 & 100 \\
\hline
\end{tabular}

Sumber: Data diolah tahun 2021

Pemberian motivasi kerja pada responden baik motivasi intrinsik maupun ekstrinsik dilaksanakan dengan baik dimana sebanyak 12 responden menilai dilaksanakan, sebanyak 3 responden menilai kurang dilaksanakan dan 2 responden menilai tidak dilaksanakan. Hal tersebut diperkuat pula dari pengamatan langsung penulis dimana pegawai Kantor Unit Pelaksana Teknis Dinas (UPTD) Pendidikan Kecamatan Tanete Riattang Barat Kabupaten Bone menunjukkan semangat kerja yang tinggi, ini pertanda memiliki rasa kepuasan yang tinggi.

\section{Controlling atau Pengawasan}

Pengawasan atau kontrol diartikan sebagai rangkaian kegiatan memelihara dan menjaga agar sikap pegawai selalu melaksanakan tugas-tugasnya secara tepat, benar dan efisien, baik dari segi waktu maupun penggunaan sumber kerja yang lain.
Dengan demikian pengawasan dimaksudkan bukan merupakan kegiatan mencari kesalahan pegawai dalam bekerja untuk dijatuhi sanksi atau hukuman sebagai perwujudan pengawasan yang bersifat kuratif. Pengawasan dimaksud difokuskan pada usaha mencegah terjadinya kesalahan-kesalahan, yang dilakukan dengan memberi bimbingan, petunjuk dan pengarahan sebelum kesalahan itu bertambah berat dan sulit diperbaiki. Pengawasan seperti itu diartikan sebagai pengawasan preventif, yang dilakukan sebelum kesalahan atau kekeliruan dilakukan.

Dari pengertian tersebut jelas bahwa tujuan pengawasan harus diarahkan pada usaha meningkatkan kesadaran untuk memahami tata tertib/disiplin kerja dan disiplin waktu, guna meningkatkan daya dan hasil guna dalam pelaksanaan tugas masing-masing. Pada giliran berikutnya berarti pengawasan dimaksud juga untuk meningkatkan motivasi dan moral kerja dan membiasakan bekerja secara cermat, teliti dan tekun. Untuk itu langkah pertama yang ditempuh adalah melakukan pengawasan atau ketepatan hadir dan pulang setelah melaksanakan pekerjaan sesuai dengan ketentuan yang berlaku.

Uraian tersebut di atas dapat diamati pada tabel berikut tentang pendapat responden.

Tabel 4. Pelaksanaan Pengawasan

\begin{tabular}{|c|l|c|c|}
\hline No & \multicolumn{1}{|c|}{ Kriteria } & Frekuensi & $\%$ \\
\hline 1 & Dilaksanakan & 10 & 58,82 \\
2 & Kurang dilaksanakan & 5 & 29,41 \\
3 & Tidak dilaksanakan & 2 & 11,77 \\
\hline & Jumlah & 17 & 100 \\
\hline
\end{tabular}

Sumber: Data diolah tahun 2021

Tabel di atas menggambarkan tentang pelaksanaan pengawasan dimana dari 17 responden yang menilai bahwa pengawasan dilaksanakan sesuai langkah-langkah dan perangkat-perangkat yang ada sebanyak 10 responden, terdapat 5 responden menilai pengawasan kurang dilaksanakan, dan sisanya 2 responden menilai pengawasan tidak dilakukan. Melihat perimbangan penilaian responden, 
dapat diasumsikan pelaksanaan pengawasan pada Kantor Unit Pelaksana Teknis Dinas (UPTD) Pendidikan Kecamatan Tanete Riattang Barat Kabupaten Bone belum memadai, oleh karena pelaksanaan pengawasan tidak maksimal

\section{B. Faktor- faktor yang mempengaruhi Peningkatan kinerja Pegawai}

1. Faktor Budaya Pegawai

Setiap organisasi yang pada awalnya terbentuk atas dasar pelayanan publik, sangat mungkin membutuhkan sumber daya manusia yang handal dan menguasai akan tugasnya sebagai bawahan dari pimpinan. Kebiasaan-kebiasaan yang seringkali muncul pada kelompok atau organisasi seperti di Kantor Unit Pelaksana Teknis Dinas (UPTD) Pendidikan Kecamatan Tanete Riattang Barat Kabupaten Bone adalah kebiasaan pada setiap individu pegawai sulit diterima oleh sesama rekan pegawai, misalnya kurang bersahabat dalam bekerja dengan si A atau si B, dia maunya dengan si C. keinginan semacam ini memerlukan pengertian khusus.

Kebiasaan-kebiasaan seperti ini yang penulis maksudkan sebagai faktor budaya pegawai yang sulit disesuaikan keberadannya pada setiap individu, dan ini menjadi togas berat sebagai pemimpin yang berusaha berlaku mendekati keadilan pada setiap pegawai. Pada tabel berikut digambarkan tanggapan pegawai Kantor Unit Pelaksana Teknis Dinas (UPTD) Pendidikan Kecamatan Tanete Riattang Barat Kabupaten Bone tentang bagaimana faktor budaya pegawai di dalam kantor pada jam kerja.

Tabel 5. Tanggapan Responden Tentang Faktor Budaya Pegawai di Kantor Unit Pelaksana Teknis Dinas (UPTD) Pendidikan Kecamatan Tanete Riattang Barat Kabupaten Bone

\begin{tabular}{|l|l|l|l|}
\hline No & Tanggapan & $\begin{array}{c}\text { Jumlah } \\
\text { (Orang) }\end{array}$ & Prosentase \\
\hline
\end{tabular}

\begin{tabular}{|c|c|c|c|}
\hline 1 & Sangat Baik & 0 & 0 \\
2 & Baik & 15 & 88,23 \\
3 & Cukup & 2 & 11,77 \\
4 & Kurang & 0 & 0 \\
\hline & Jumlah & 17 & $100 \%$ \\
\hline
\end{tabular}

Sumber: Hasil Olahan Data, 2021

Hasil kuesioner menunjukkan bahwa, pegawai pada kantor Kantor Unit Pelaksana Teknis Dinas (UPTD) Pendidikan Kecamatan Tanete Riattang Barat Kabupaten Bone berpendapat baik 15 orang. Sedangkan yang berpendapat cukup 2 orang dan (0\%) menyatakan kurang. Nilai presentase hasil kuisioner menunjukkan bahwa masalah faktor budaya pegawai berpengaruh terhadap peningkatan kinerja.

2. Faktor Situasi Lingkungan Kerja

Pada penjelasan kerangka konsep pada bab di muka menjelaskan bahwa dalam interaksi antara pemimpin dengan anggota organisasi sebagai bawahan seperti suasana atau iklim kerja. Suasana dimaksudkan adalah di lingkungan pekerjaan di kantor.

Dengan kondisi lingkungan kerja yang pemimpinnya bersahabat, suportif, dan pengarah (direktif), ini sangat berpengaruh terhadap peningkatan kinerja pegawai. Tidak terjadi dengan kondisi sebaliknya menimbulkan petaka.

Tabel 6. Tanggapan Responden tentang Faktor Situasi Lingkungan Kerja dalam Menunjang Keberhasilan Pekerjaan.

\begin{tabular}{|c|c|c|c|}
\hline No & Tanggapan & $\begin{array}{c}\text { Jumlah } \\
\text { (Orang) }\end{array}$ & Prosentase \\
\hline 1 & Sangat Baik & 3 & 17,65 \\
2 & Baik & 10 & 58,82 \\
3 & Cukup & 3 & 17,65 \\
4 & Kurang & 1 & 5,88 \\
\hline & Jumlah & 17 & $100 \%$ \\
\hline
\end{tabular}

Sumber: Hasil Olahan Data, 2021

Dari hasil kuesioner di atas telah menggambarkan bahwa, pegawai yang 
berpendapat sangat baik 3 orang, berpendapat baik 10 orang dan yang berpendapat cukup juga 3 orang dan 1 orang menyatakan kurang dari 17 total responden.

Kesimpulannya adalah masih sebagian besar pegawai menilai baik atas faktor situasi lingkungan kerja itu berpengaruh besar terhadap peningkatan kinerja pada Kantor Unit Pelaksana Teknis Dinas (UPTD) Pendidikan Kecamatan Tanete Riattang Barat Kabupaten Bone.

3. Kuantitas dan Kualitas Kinerja

Sebagai pemimpin, Lurah merupakan pusat perhatian dari setiap bentuk kegiatan layanan kepada masyarakat publik sebagai penanggung jawab pelaksanaan tugas kepemimpinan di wilayah Kantor Unit Pelaksana Teknis Dinas (UPTD) Pendidikan Kecamatan Tanete Riattang Barat Kabupaten Bone. Mutu dan banyaknya tanggung jawab yang diemban tidak menjadi hambatan untuk tetap bekerja, beban ini diperuntukkan oleh pegawai bersama pemimpinnya.

Keinginan masyarakat mengharapkan agar setiap kebutuhan dasar di wilayah kerja Kantor Unit Pelaksana Teknis Dinas (UPTD) Pendidikan Kecamatan Tanete Riattang Barat Kabupaten Bone dengan mudah terpenuhi. Pemenuhan akan pelayanan dasar seperti kemudahan memperoleh kartu tanda penduduk (KTP), Kartu Keluarga, Akta Kelahiran dan lain sebagainya.

Terpenuhinya hat-hal di atas, dianggapnya bahwa kualitas kinerja kita menggembirakan. Berikut perhatikan tabel di bawah ini.

Tabel 7. Tanggapan Responden tentang peranan pemimpin terhadap peningkatan kualitas dan kuantitas kinerja.

\begin{tabular}{|l|l|l|l|}
\hline No & Tanggapan & $\begin{array}{c}\text { Jumlah } \\
\text { (Orang) }\end{array}$ & Prosentase \\
\hline
\end{tabular}

\begin{tabular}{|c|c|c|c|}
\hline 1 & Sangat Baik & 3 & 17,65 \\
2 & Baik & 11 & 64,71 \\
3 & Cukup & 3 & 17,64 \\
4 & Kurang & 0 & 0 \\
\hline & Jumlah & 17 & $100 \%$ \\
\hline
\end{tabular}

Sunber: Hasil Olahan Data, 2021

Peningkatan kualitas dan kuantitas kinerja pegawai pada umumnya disetiap unit kerja adalah suatu hal yang mesti dilaksanakan. Dengan demikian kita dapat mengetahui tingkat perkembangan ataupun kemajuan, bahkan kemunduran sekalipun dapat terlihat dengan jelas, sehingga pemimpin mudah melakukan perubahan bila terdapat kesalahan-kesalahan.

Untuk mengetahui ada tidaknya peningkatan kuantitas dan kualitas kinerja pemimpin harus banyak berperan. Pada tabel di atas menunjukkan hasil kuisioner bahwa ada 3 orang memperlihatkan hasil sangat baik, 11 orang mengatakan baik dan 3 orang lagi berpendapat cukup.

Melihat pendapat tersebut di atas, ternyata peranan pemimpin dapat menentukan tingkat perkembangan kualitas kinerja yang sebagian besar berpendapat baik.

Dari data hasil survei dapat terlihat bahwa di Kantor Unit Pelaksana Teknis Dinas (UPTD) Pendidikan Kecamatan Tanete Riattang Barat Kabupaten Bone, penilaian kinerja lebih dipengaruhi oleh bagaimana pemimpin berperan aktif dalam mendukung kinerja para pegawainya. Perhatikan tabel berikut ini.

Tabel 8. Tanggapan Responden tentang Penilaian Kinerja Pegawai yang harus dihargai sebagai tanggung jawab Pemimpin.

\begin{tabular}{|c|c|c|c|}
\hline No & Tanggapan & $\begin{array}{c}\text { Jumlah } \\
\text { (Orang) }\end{array}$ & Prosentase \\
\hline 1 & Sangat Baik & 0 & 0 \\
2 & Baik & 15 & 88,23 \\
3 & Cukup & 2 & 11,74 \\
4 & Kurang & 0 & 0 \\
\hline
\end{tabular}




\begin{tabular}{|l|c|c|c|}
\hline & Jumlah & 17 & $100 \%$ \\
\hline
\end{tabular}

Sumber: Hasil Olahan Data, 2021

Hasil kuesioner tentang penilaian kinerja pegawai menunjukkan bahwa 15 orang berpendapat baik, dan hanya 2 orang menilai cukup, menyatakan bahwa penilaian kinerja harus dihargai sebagai tanggung jawab pemimpin.

Ini artinya bahwa kinerja seorang pegawai mempunyai andil besar terhadap kemajuan kegiatan-kegiatan urusan kantor dalam menyelesaikan tugas atas tuntutan masyarakat akan pelayanan.

\section{KESIMPULAN}

1. Penerapan sistem administrasi terhadap peningkatan kinerja pegawai telah optimal dan dilakukan melalui kemampuan kerja, motivasi kerja, pengalaman dalam melaksanakan tugas- tugas administrasi perkantoran.

2. Peran pemimpin dan dukungan pegawai, juga tidak sulit mengarahkan, meningkatkan kerjasama internal kantor maupun di lingkungan masyarakat. Hasil responden pegawai menunjukkan bahwa penerapan sistem administrasi dalam meningkatkan kinerja banyak dipengaruhi oleh pemimpin itu sendiri.

\section{Saran}

Sebagai sumbangan pemikiran penulis dalam upaya lebih meningkatkan kualitas kinerja pegawai pada Kantor Unit Pelaksana Teknis Dinas (UPTD) Pendidikan Kecamatan Tanete Riattang Barat Kabupaten Bone, dipandang perlu juga peningkatan sarana kantor yang memadai dan dibenahi sesuai dengan sarana kantor yang relatif berimbang. Melalui media ini penulis menyampaikan saransaran sebagai berikut:

1. Faktor terpenting pada lingkungan kerja di kantor adalah membangun dinamika kebersamaan, disiplin, dan kreatifitas kinerja.
2. Memaksimalkan kegiatan kelembagaan agar peningkatan pemberdayaan masyarakat berkelanjutan, sehingga pada akhirnya turut andil dalam kegiatan pembangunan.

\section{DAFTAR PUSTAKA}

Andry Sutardy, MBA. Damini, Engkoam. Drs. H. Pokok-Pokok Ilmu Administrasi dan Manajemen. Penerbit MSP. Jakarta.

Dwiyanto, Agus. dkk 2002. Reformasi Birokrasi Publik di Indonesia. BPFEUGM. Yogyakarta.

Handayaningrat Soewarno. 2008. Pengantar Studi Ilmu Administrasi dan Manajemen. CV. Rajawali, Jakarta

Padhazur. 2000. Motivasi dan Kepemimpinan. Bumi Aksara, Jakarta.

Pamudji. 2007. Administrasi Kepegawaian, CV. Rajawali, Jakarta

Poerwadarminta. 2004. Administrasi Pemerintahan Dalam

Pembangunan Nasional. Gunung Agung, Jakarta.

Siagian, Sondang P. 2002. Manajemen Sumber Daya Manusia. Penerbit Bumi Aksara. Jakarta.

Siagian, Sondang P. 2003. Filsafat Administrasi. Bumi Aksara. Jakarta.

Singarimbun, Mash dan Sofian Effendi, 2009, Metode Penelitian Survey, LP3ES, Jakarta.

Sugiono. 2011. Metode Penelitian Statistik. BPFE, Gadjah Mada, Yogyakarta

Syariie Kencana. 2003. Sistem Administrasi Negara. Bumi Aksara. Jakarta

The Liang Gie, 2008. Administrasi Perkantoran Modern, Liberty, Yogyakarta.

Thoha, Miftah. 1993. Perilaku Organisasi : Konsep Dasar dan Aplikasinya. Rajawali Pers. Jakarta

Wahjosumidjo. 2004. Kepemimpinan dan Motivasi. Ghalian Indonesia. Jakarta.

Waldo Dwight. 2001. Pengantar Studi Publik Administrasi. Sumber. Bandung 
Widjaja A. W., 2009, Administrasi Kepegawaian, CV. Rajawali, Jakarta 